\title{
PROBLEMS OF RAINWATER MANAGEMENT: A CASE STUDY OF THE CITY OF WARSAW, POLAND
}

\author{
JAROSŁAW CHUDZICKI \\ Faculty of Building Services, Hydro and Environmental Engineering, \\ Warsaw University of Technology, Poland
}

\begin{abstract}
The article presents the current problems of drainage of rain sewage from the urban agglomeration area on the example of Warsaw, the capital of Poland. The size of the precipitation and its diversification, both during and in intensity in a given area is associated primarily with the climatic zone, geographical factors and the degree of urbanization of this area. Climate changes in recent years are not without significance, which are a probable cause of rainfall of above-average intensities and durations. The article presents examples of surface flooding particularly important due to the complexity of the existing infrastructure within Warsaw in recent years. It also describes the specific development of some areas within the city, such as the area of the airport. Due to the increasing operational problems associated with the discharge of rainwater from intensively urbanized areas, the legal, organizational and technical solutions applied in the agglomeration are presented. These are prohibitions for discharging rainwater from new urbanized areas, use of rainwater infiltration in a greater extent at the place of their appearance, use of retention reservoirs near sealed surfaces, more use of canal retention or use of rainwater for economic purposes (e.g. flushing toilets inside buildings). The summary states that it is difficult to assess at the moment whether the presented solutions will actually minimize the growing problems associated with atmospheric precipitation in the Warsaw agglomeration.
\end{abstract}

Keywords: urban drainage, surface flooding, rainwater management.

\section{INTRODUCTION}

Since the 1990s, the increased influence of climate change at local weather conditions in Poland has been indicated. Poland is in the transitional climate zone, between maritime and continental. It is in the zone of moderate climates.

Over the last 30 years, milder winters with decreasing snowfall have been observed.

For the past few years, the fact of appearing the snow cover in Warsaw has been an real incident (Fig. 1). On the other hand, there are hotter and hotter summer seasons.

On such background of seasonal changes, more and more frequent occurrence of relatively short-term extreme weather phenomena is observed: storms with hail, whirlwinds, hurricanes [1], [2]. These phenomena also include short-term temperature anomalies, eg. the occurrence of sub-zero temperatures in the summer (May, June) and relatively longer periods with the temperatures above $+10^{\circ} \mathrm{C}$ in the winter season (January, February).

This article presents a review of the impact of climate change that has occurred over the last several decades on wastewater management within Warsaw agglomeration, as an example of a large urban settlement unit in Poland. The catchment, from which rainwater is discharged, has been characterized. The problems that have emerged in this area, particularly in recent years, have been identified. The solutions that were applied, in order to minimize the adverse effects of climate anomalies, in the legal, administrative and technical spheres have also been presented. 


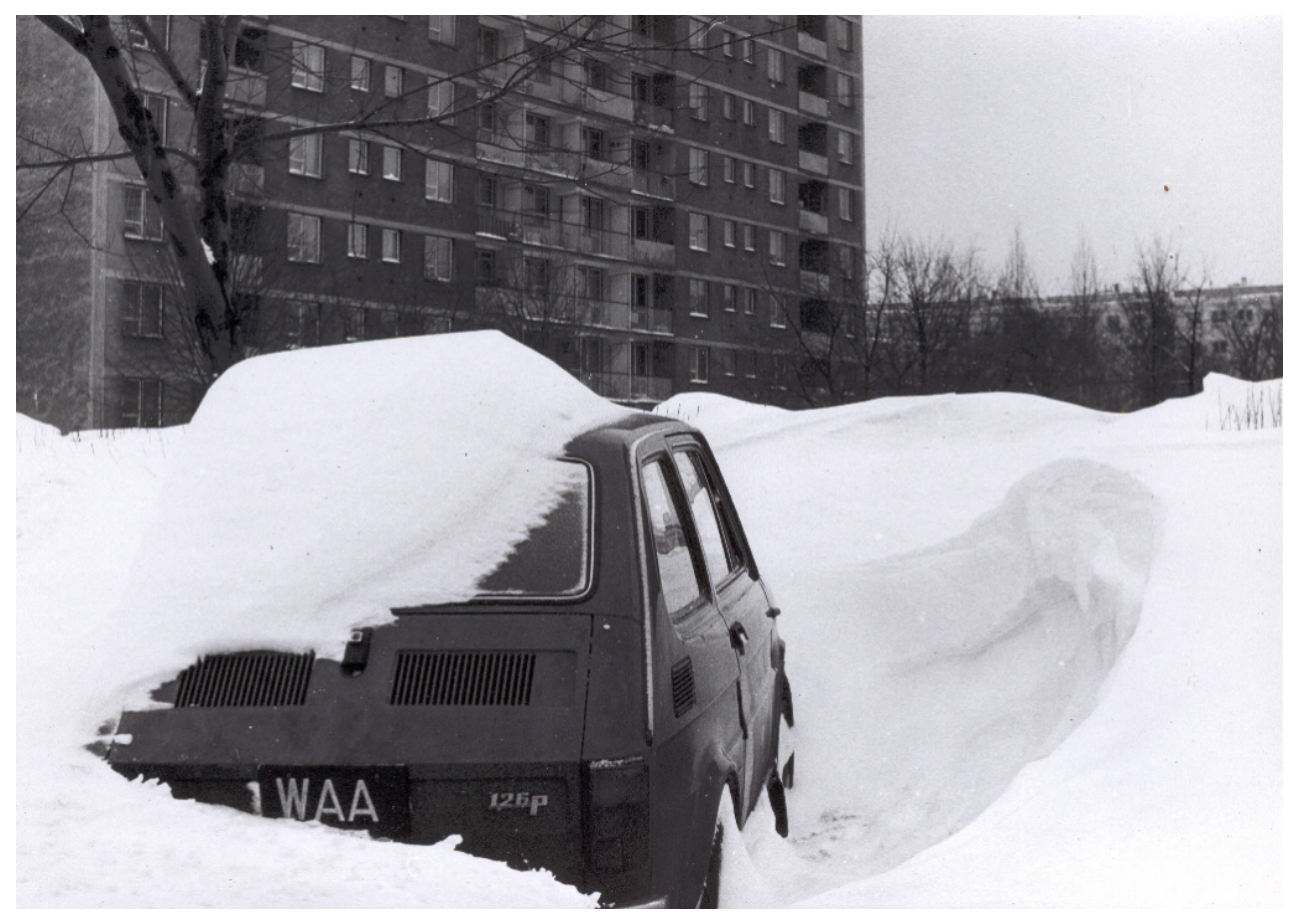

Figure 1: Snowfall in January 1979, Warsaw, Muranów housing estate [3].

\section{THE CATCHMENT FEATURES IN THE CITY CENTER}

In Warsaw, a modern sewage network was built at the turn of the 19th and 20th centuries. The designers of the sewage network were William Lindley and his son, William Heerlein Lindley, who also were the creators of sewage systems for such European cities as Frankfurt or Hamburg.

A combined sewerage network was established in the area of the city center. Only later, during the permanent expansion of the sewerage system, a separates systems were decided; sanitary sewage system and a separate rainwater drainage system. In 1925, the total length of the sewage network in Warsaw was $219 \mathrm{~km}$ [4].

After World War II, starting from 1945, the city was being very dynamically rebuilt after the war damage [5], [6]. The next important step in the extension of the city and its infrastructure was the political and social transformation, in Poland started in 1989. Since then, the city has been further developed, which directly affected the sealing of the catchment in the city center area (Fig. 2).

It ought to be mentioned that many important and sensitive engineering facilities have been located under the surface of the very center of the city. Some of them are:

- a railway tunnel running under the center of Warsaw from east to west;

- Warsaw Central Railway Station;

- $\quad 1$ st and 2nd line of underground and its stations;

- numerous underground pedestrian crossings;

- underground multi-storey garages. 


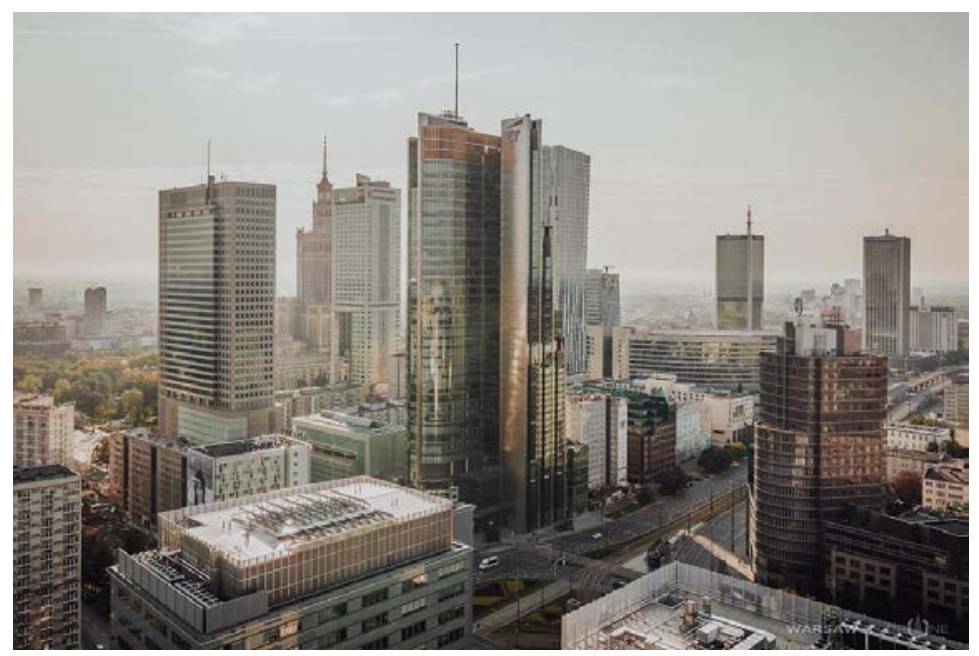

Figure 2: The current view of a part of the center of Warsaw [7].

At present, the total length of the sewage network in Warsaw is over $3500 \mathrm{~km}$ with diameters up to $3500 \mathrm{~mm}$. Over 80 pumping stations works with the sewage system [8].

\section{IDENTIFICATION OF PROBLEMS}

Changes in the spatial development of the city affected the quantity and quality of discharged rainwater to the sewage system. The catchment tightness increased relatively within the city center area.

The sewage system discharging rainwater was designed for a catchment with less tightness, which is why the capacity of the existing sewage system is frequently exceeded.

These phenomena occur especially from May to June, when precipitation occurs with the intensities which exceed the computational intensity, or which last longer than the precipitation times which were accepted while dimensioning the sewage system in the 20th century.

The mentioned above historical changes and the current situation with the catchment in the center of Warsaw combined with the observed climate changes generate a lot of significant problems of various quantitative and qualitative scale. In the last 50 years, an increase in average temperature has been observed in central Poland, especially in the winter season: from 0.3 to $0.7^{\circ} \mathrm{C} / 10$ years [9], [10]. Seasonal warming also has an effect on the seasonal variability of precipitation: winters are warmer and drier, and during the summer there is an increased rainfall [11].

There happens frequent flooding of the underground objects during torrential rains, which occur in Warsaw most often within May and June period (Figs 3 and 4).

Flooding the surface occurs most often in the places located at the lowest level areas, in Vistula River neighbourhood. The most frequent flooding takes place during storm water runoff by storm collectors, special sewer collectors with large diameters (about 2.0-2.5 m), whose task is to relieve the sewage system from excess flows of rain sewage (Fig. 5).

Flooding the surface by rain sewage draining out of the sewage network also causes sanitary danger for water supply networks and for the natural environment [14]. In June 2013, during the extremely long-lasting heavy rain of extreme intensity, the Toruńska 


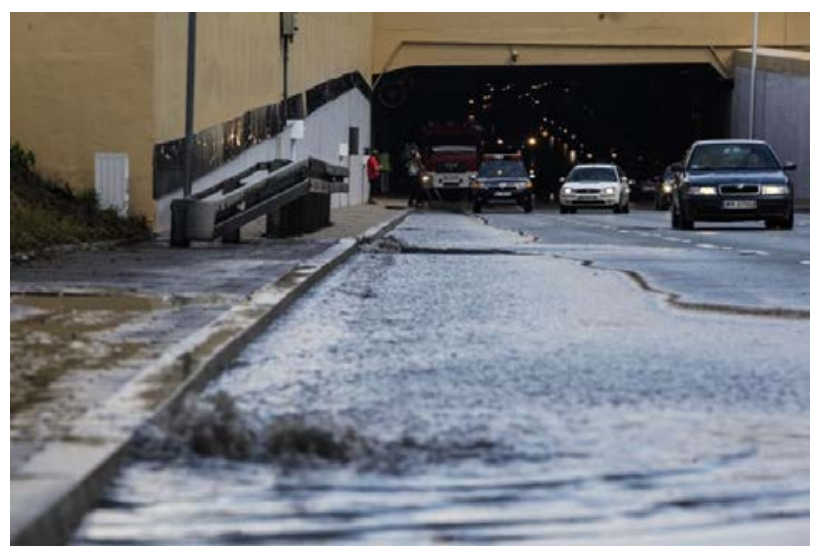

Figure 3: Flooding the tunnel along the Vistula River after heavy rains. In the foreground the outflow of rain sewage from the flooded sewage system through a street gully is visible [12].

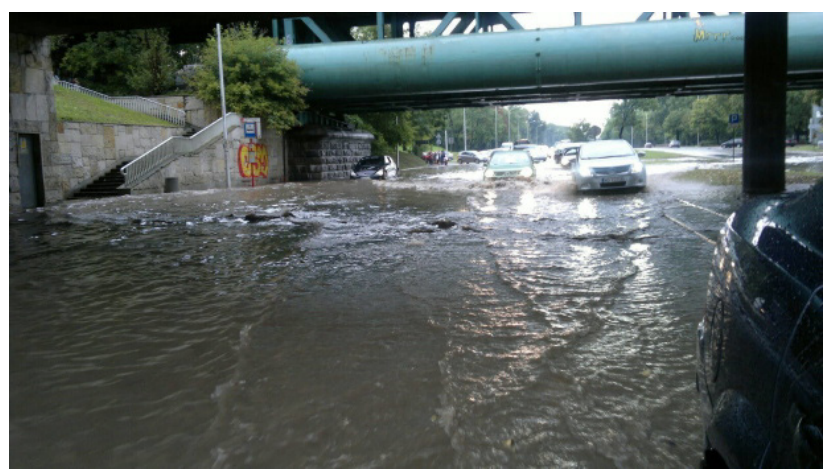

Figure 4: Flooded Wisłostrada under the Gdańsk bridge in Warsaw as a result of torrential rain [13].

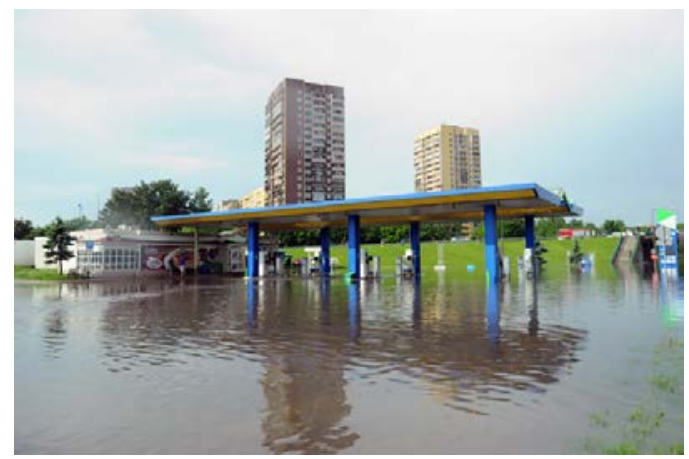

Figure 5: Petrol station flooded by torrential rain at the Toruńska Route in Warsaw on 9/06/2013 [15]. 
Route motorway along with adjacent infrastructure, including petrol stations and Passenger Service Areas etc, was flooded (Fig. 5).

The areas in the city, which are operated in a specific way in terms of drainage of rainwater, should also be mentioned at that moment. What is meant, here is the International Frederic Chopin Airport in Warsaw, which at the time of its construction (in the 1920s) was located outside the administrative borders of the city, and currently is located within the administrative borders of the city, few minutes' drive from its center (Fig. 6).

Due to the air traffic intensity and flights safety, rainwater from the surface of runways and ground runs have to be discharged in a very short time.

The problem with atmospheric precipitation occurs at the airport during autumn and winter periods when air and surface temperatures are close or below the $0^{\circ} \mathrm{C}$. In such situations icing of the airport surface appears, which has a direct impact on the safety of taking off and landing planes. For the very quick de-icing of runway surfaces and ground runs the specialized chemicals are used at the airport (Fig. 7).

In the case of long-term use of anti-icing chemicals, there is a danger of high concentrations of these substances in rain wastes discharged to the Służewiecki Stream, which is a natural catchment from areas belonging to the airport. Concentrations of pollutants are on-line monitored in the outflow of rainwater from the area of airport and in the case of exceeding the permissible concentrations of these pollutants, all the outflow are diverted to the sanitary sewage system, through which sewage are transferred to the municipal sewage treatment plant Warsaw-South [16].

An additional problem is the de-icing of planes before their take-off. For those purposes chemical substances are used that cannot be discharged along with rainwater (Fig. 8). Because of that, de-icing of a planes take place on specially separated de-icing platforms, from which sewage is discharged gravitationally into sealed reservoirs, and afterwards exported outside the airport for chemical utilization.

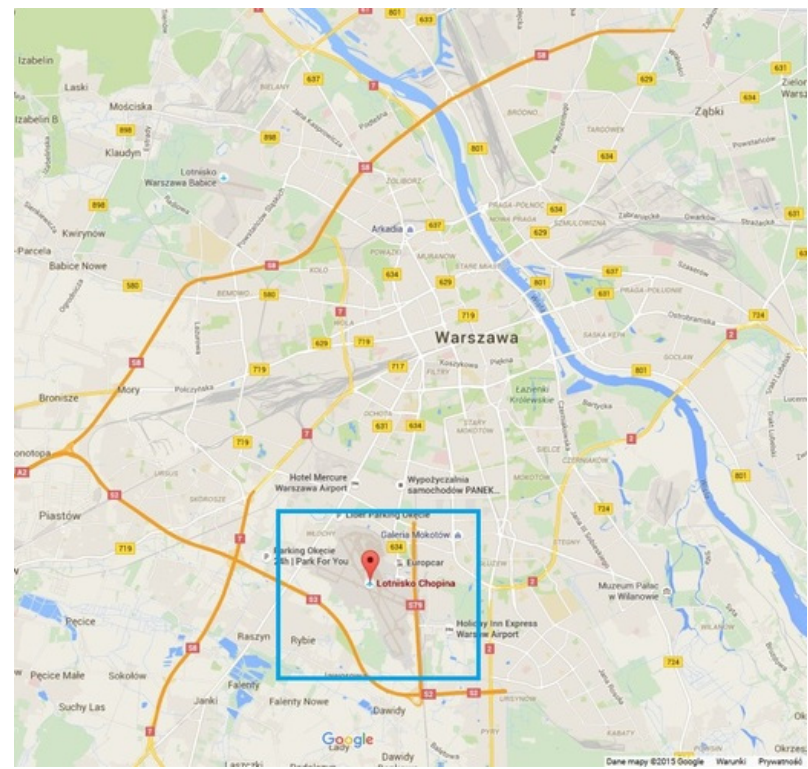

Figure 6: Location of the International Frederic Chopin Airport in Warsaw. 


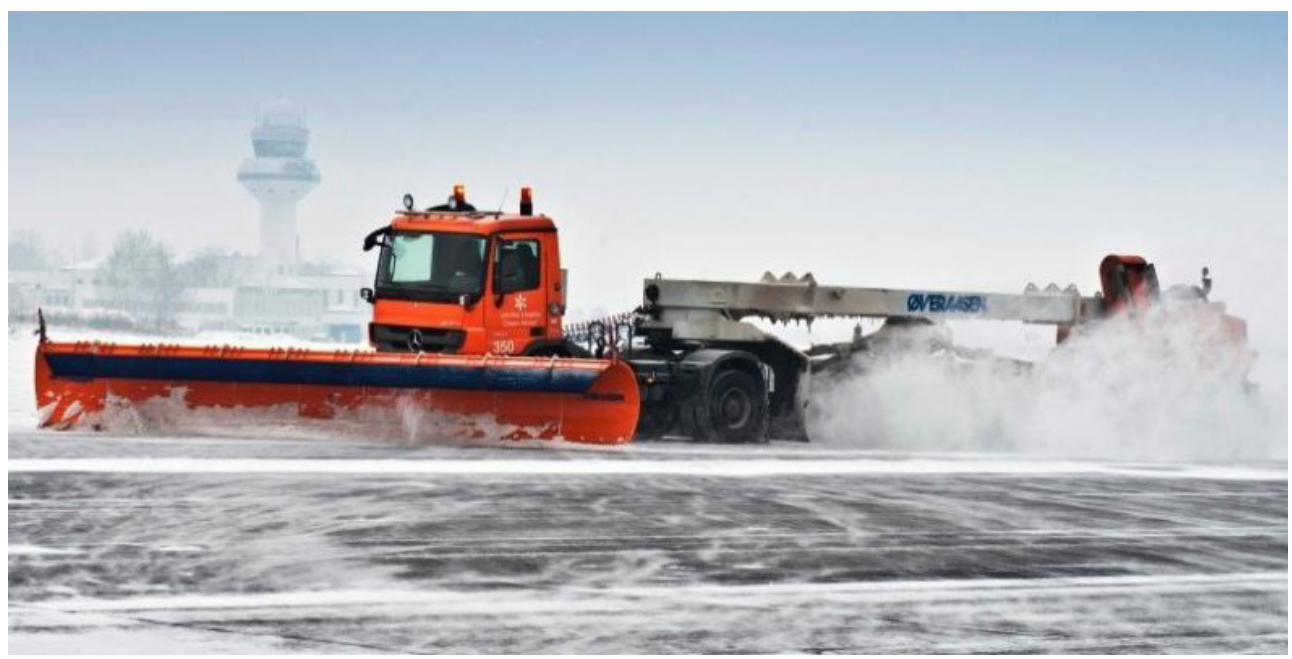

Figure 7: Snow removal from runways at the International Frederic Chopin Airport in Warsaw with the use of technical equipment and chemicals [17].

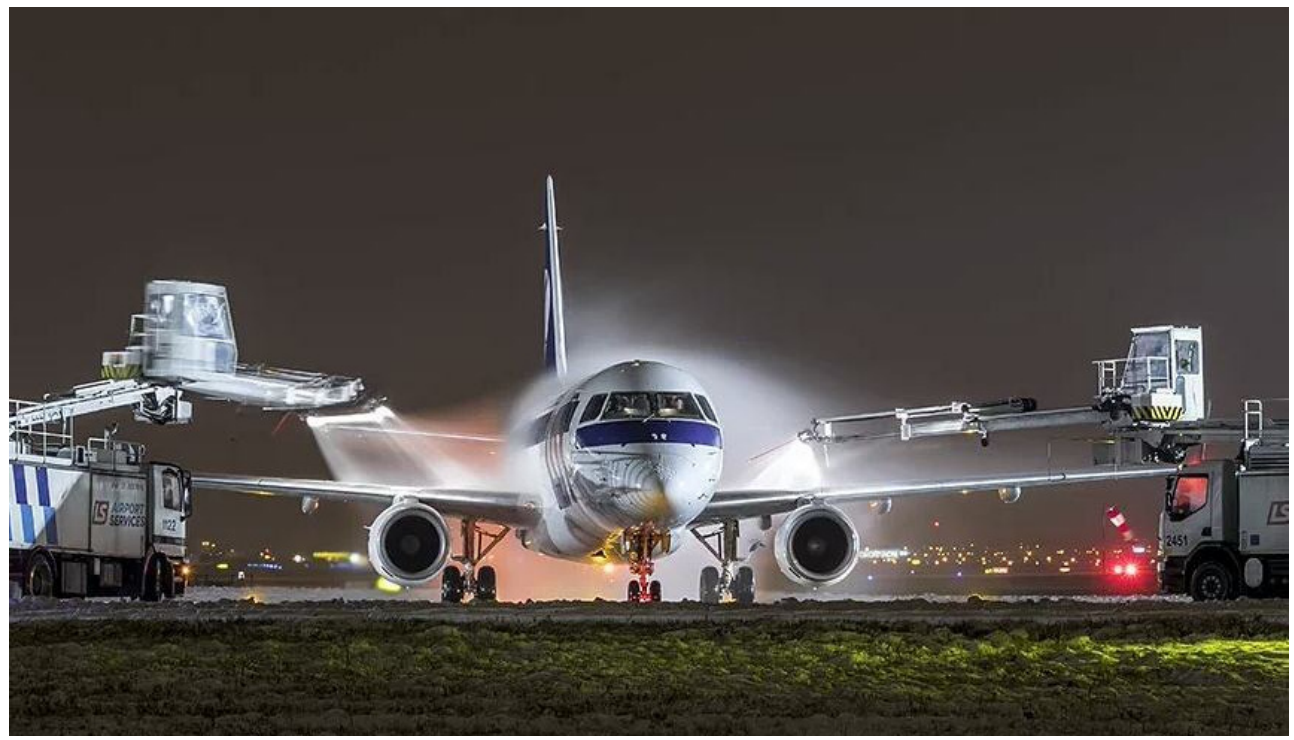

Figure 8: The International Frederic Chopin Airport in Warsaw. De-icing a plane with chemicals on a special parking platform [18].

The main criterion for wastewater management at the airport is protecting the environment of natural watercourses, to which atmospheric precipitation from the airport area flows gravitationally. The solutions applied are, however, quite costly, which influences the profitability of the airport located close to the city center [16]. 


\section{APPLIED SOLUTIONS OF RAINWATER SEWAGE MANAGEMENT IN THE CITY}

Increasing problems with the discharge of excess rainwater in the city center made the authorities and technical services maintaining the city apply a number of solutions in the legal, organizational and technical areas.

For several years, there has been the ban on discharging rainwater during rainfall to the municipal sewage system. This situation applies to newly designed buildings and to the ones exploited within the city center area. In such cases, designers of sewage systems in new buildings are obliged to provide the necessary retention of rainwater discharged from the roof slopes and from the areas adjacent to the building.

In technical terms, this situation is resolved in such a way that the rainwater retention reservoirs are located inside buildings (usually in underground storeys) (Fig. 9). After the precipitation, the collected rainwater can be discharged to the external rainwater sewage system (in the period of, so called, rainless weather). In the buildings that are implemented in accordance with the certificates for energy-efficient buildings (LEED or BREEAM certificates are most frequently used in construction in Poland), rainwater collected after initial pre-treatment and disinfection is used together with greywater to flush toilets inside a building or to maintain greenery on roofs, terraces and the area around the building.

In terms of planning the spatial development of Warsaw agglomeration, a wide application of surface retention combined with rainwater drainage channels from Warsaw catchment was introduced [19]. In recent years a number of open reservoirs have been built in the largest catchment area in Warsaw, the Służewiecki Stream catchment (Fig. 10): these are Berensowicz Ponds, the Wyścigi Pond and the largest Służewiecki Pond. These reservoirs also play a recreational role for the residents of the city, and when large precipitation occurs they make it possible to take over and stop part of the runoff of rainwater (Fig. 11).

Apart from retention reservoirs, in the spatial development planning, technical solutions that enable the discharge of rainwater through infiltration into the ground. Drains and drainage boxes are used in such cases.

From January 1, 2018, the new Water Law Act [20] came into force, according to which charges for drainage of rainwater to municipal sewage systems are calculated. These

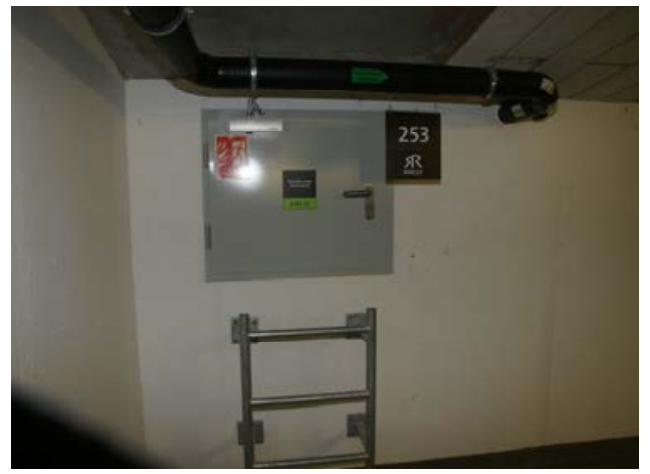

(a)

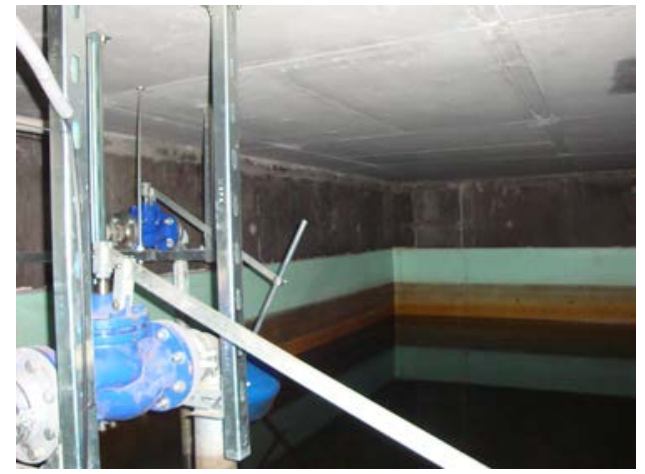

(b)

Figure 9: Rainwater retention tank inside the building. (a) Manhole to the reservoir from an underground garage under the building; (b) View of the reservoir interior. 


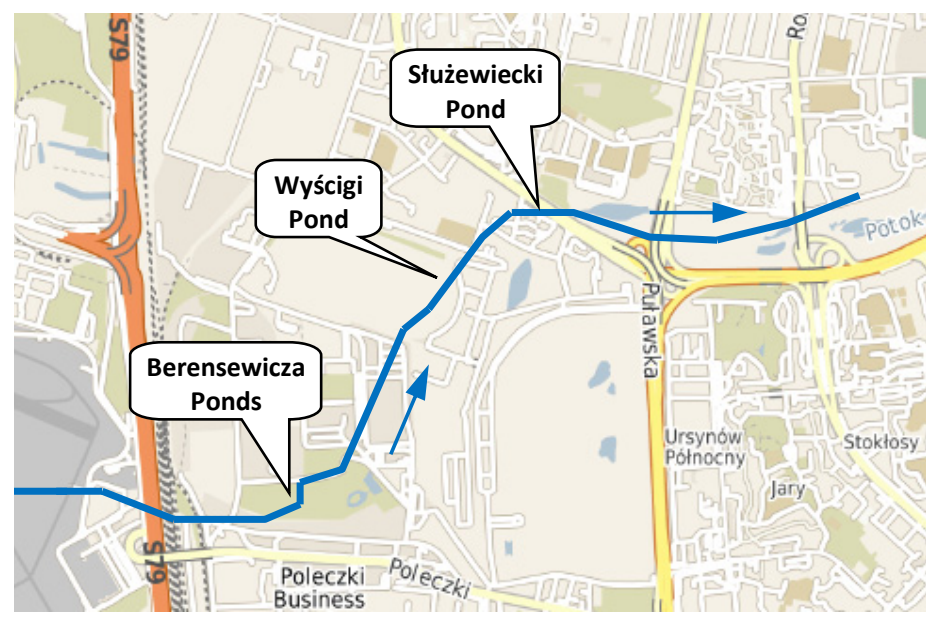

Figure 10: The location of artificial retention reservoirs in the upper Służewiecki Stream course below the area of the International Frederic Chopin Airport in Warsaw.

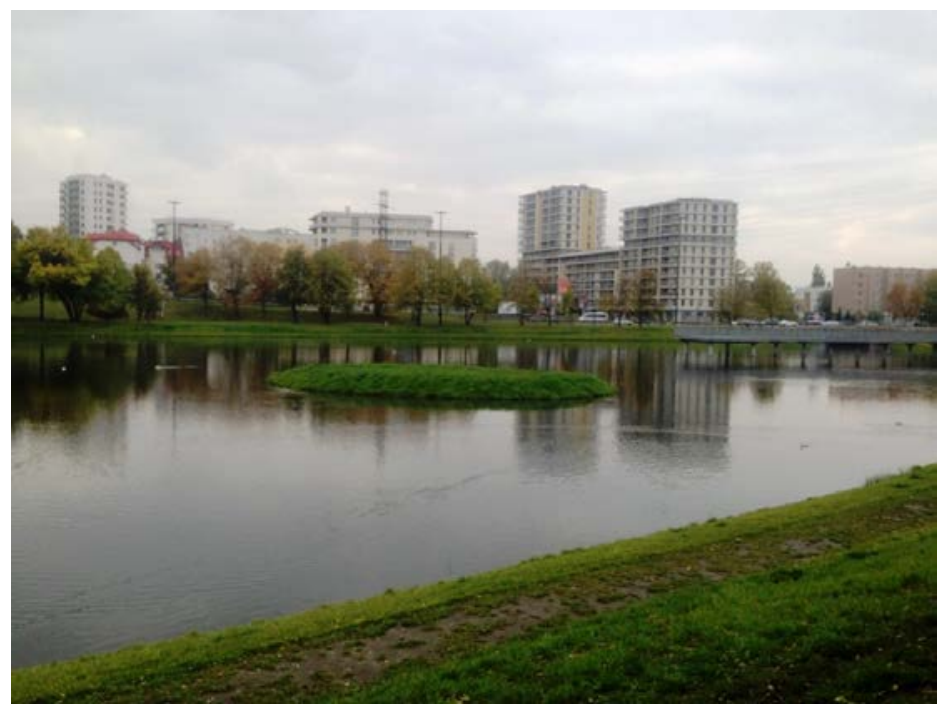

Figure 11: View on the Służewiecki Pond.

regulations currently apply only to institutions, but in the future, obliging private owners of buildings and premises to pay charges is also considered [21]. This economic instrument is meant to make the owners of buildings and properties use rainwater in its place of occurrence as much as possible instead of draining it to the sewage system.

Another technical solution that was introduced during the extension of the sewage system infrastructure in Warsaw is to increase the channel retention. This is realised during the construction of new sections of sewage collectors by intentionally increasing the crosssection of the sewage pipe. An example of such solution can be a built section of the 
"Burakowska-Bis" combined sewer collector in Marymoncka Street in Warsaw. The collector parameters are as follows:

- diameter: $3200 \mathrm{~mm}$;

- length: $3 \mathrm{~km}$.

Due to the location of the collector under one of the main communication arteries in the northern part of Warsaw, there was a decision to use trenchless technology (Fig. 12). The tunnel for the collector itself was made by the microtunneling method with a use of a shield - it was the largest investment in sewage infrastructure in Europe in recent years [8].

The solution of the sewer collector performing the retention function enables it to delay the flow of sewage from the agglomeration to the sewage treatment plant. In this way, maximal sewage flow rates can be reduced by extending their flow time in the sewage system.

\section{SUMMARY - WILL THE PRESENTED ACTIVITIES BE SUFFICIENT?}

The impact of climate changes observed in the last few decades on managing rainwater sewage in Warsaw agglomeration has been presented in the article.

Basing on the actions mentioned, it can be concluded that the legal, organizational and technical measures taken so far are enough to preserve the correct exploitation of the rainwater sewage system in Warsaw at the moment.

But the question that arises is whether the measures taken so far are sufficient for future? How will the climate in Europe change and what impact will these changes have on our lives?

At the present moment, it is difficult to answer such general questions unambiguously.

From the information presented in the article, it can be concluded that the construction of a rainwater sewage system within the settlement unit does not solve the problem of wastewater management once and for all.

What we deal with are a great number of parameters that are variable and which directly or indirectly affect the amount of sewage discharged, its composition, as well as the intensity of flows in the sewage system.

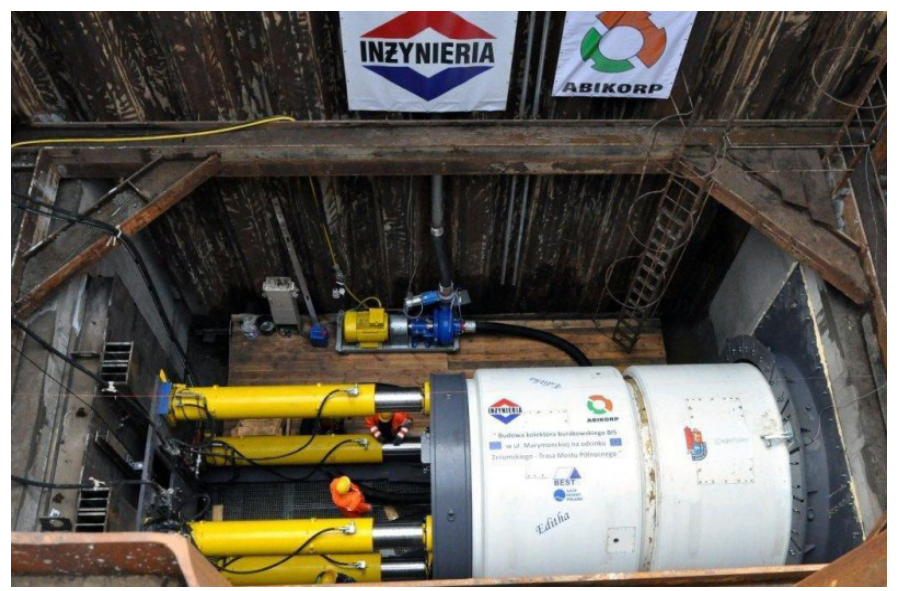

Figure 12: View of the starting chamber with the TBM disc for drilling the tunnel for the "Burakowska-Bis" collector [22]. 
The sewage system is designed according to the precipitation data forecasted and predicted on the basis of the previous meteorological observations. But, when these parameters change, it is not possible to change the diameters of sewage pipes that already exist.

Therefore, it is important to use alternative solutions that can be used independently in the existing sewage system.

It seems that the solutions such as direct drainage of rainwater to the ground (infiltration sewage), the use of retention reservoirs and the natural shape of the area for temporary retention of excess rainwater are solutions that significantly decrease the danger of sewer overflows or flooding of the surface.

On the other hand, we also have to be prepared to give up the use of a particular area on the current conditions.

An example could be the recent decision of state authorities in Poland to build a new international airport outside of Warsaw (in Baranów, about $40 \mathrm{~km}$ from Warsaw), which, in the future, will take over all the air traffic from the current International Frederic Chopin Airport in Warsaw.

This decision was influenced by a lot of various factors, but the factor connected with the high costs of rainwater drainage from the area of the current airport was also taken into consideration.

\section{REFERENCES}

[1] Żmudzka, E. et al., Mapa współczesnych zagrożeń klimatycznych m. st. Warszawy wraz z komentarzem (Map of contemporary climate threats of the Capital City of Warsaw with a commentary). Project LIFE13 INF/PL/000039 LIFE ADAPTCITY PL. Preparation of a strategy of adaptation to climate change with use of city climate mapping and public participation, Warszawa, 2016.

[2] Liszewska, M. et al., Klimat Warszawy w 21. wieku (The climate of Warsaw in the 21st Century). Project LIFE13 INF/PL/000039 LIFE ADAPTCITY PL. Preparation of a strategy of adaptation to climate change with use of city climate mapping and public participation, Warszawa, 2016.

[3] Photo by Tomasz, warszawa@tvn.pl.

[4] Rabczewski, W. \& Rutkowski, S. (eds), Wodociagi i Kanalizacja m. st. Warszawy 1886-1936 (Waterworks and Sewerage of the Capital of Warsaw 1886-1936), Warsaw Waterworks and Sewerage: Warsaw, 1937.

[5] Janczewski, H., Warszawa: Geneza i rozwój inżynierii miejskiej. (Warsaw: Genesis and Development of Urban Engineering), Arkady: Warszawa, 1971.

[6] Gajewski, M., Urzadzenia komunalne Warszawy. (Municipal Devices of Warsaw), PIW: Warszawa, 1979.

[7] Photo by Rafał Ganowski, Warsaw By Drone.

[8] Municipal Water and Sewerage Company (MPWiK) in Warsaw. Online. www.mpwik.com. pl/view/inwestycje/. Accessed on: 20 Apr. 2017.

[9] Michalska, B., Tendencje zmian temperatury powietrza w Polsce (Tendencies of air temperature changes in Poland). Prace i Studia Geograficzne T. 47, pp. 67-75, 02084589, 2011.

[10] Okoniewska, M., Zmiany temperatury powietrza w Polsce w XX wieku na tle cyrkulacji atmosferycznej (Changes of air temperature in Poland in XX century on the background of air circulation). Journal of Health Sciences, 3(15), pp. 130-151, 2013. 
[11] Czarnecka, M. \& Nidzgorska-Lencewicz, J., Wieloletnia zmienność sezonowych opadów w Polsce (Multiannual variability of seasonal precipitacion in Poland). Woda-środowisko-obszary wiejskie (IV-VI): t. 12 z. 2 (38), Water-EnvironmentRural Areas, pp. 45-60, 2012.

[12] Photo by PAP/Jakub Kamiński, tvpinfo.pl, 26 Jun. 2013.

[13] Photo by Dawid Krysztofiński, tvnwarszawa.tvn24.pl, 11 Aug. 2014.

[14] Chudzicki, J., Current threats to water supply system. WIT Transactions on the Built Environment, Urban Water, WIT Press: Southampton, pp. 3-14, 2016.

[15] Photo by PAP/Radek Pietruszka.

[16] Chudzicki, J. et al., Water-legal Service for Discharging from the Area "Polish Airports" State Enterprise Rainwater and Snowmelt to the Stużewiec Stream. Warsaw University of Technology: Warsaw, 2017.

[17] Photo by Łukasz Widziszowski.

[18] Photo by Zbyszek Pietrzak.

[19] Najgebauer A. (ed.), Modele zagrożeń aglomeracji miejskiej wraz z systemem zarzadzania kryzysowego na przykładzie miasta stołecznego Warszawy (Models of Threats to the Urban Agglomeration Together with the Crisis Management System Based on the Example of the Capital City of Warsaw). WAT: Warsaw, 2009.

[20] The Water Law Act (Official Journal of 2017, Item 1566).

[21] Regulation on unit rates for water services, issued by Council of Ministers on December 22, 2017 (Official Journal of 2017, Item 2502).

[22] www.kierunekwodkan.pl. Accessed on: 19 Mar. 2014. 